\title{
An exploratory study of ESL writing by junior secondary students in China: text type, register and textual features
}

\author{
Winfred Wenhui Xuan(D)
}

\author{
Correspondence: \\ winfredhuen@gmail.com \\ Division of Language and \\ Communication, Hong Kong \\ Community College The Hong \\ Kong Polytechnic University, Hong \\ Kong, Hong Kong
}

\begin{abstract}
While interest in $L 2$ writing research has increased exponentially in recent years, research on adolescent $\mathrm{L} 2$ writing remains relatively scarce. Drawing on the framework of functional text analysis, namely context-based text typology and register theory, the present study aimed to explore Chinese adolescent L2 writing from the perspective of writing as meaning making. Ten instances of writing tasks written by a class of 50 junior secondary students from Guangzhou, China were collected. Context-based text typology and field, mode tenor from register theory were used to analyze the participants' writing. The findings revealed that recommending was the dominant text type in the students' writing because of the influence of the exam-driven culture. Moreover, tenor awareness was lacking in the students' writing. Relevant Chinese secondary L2 writing curriculum design and pedagogy recommendations are provided.
\end{abstract}

Keywords: Systemic Functional Linguistics, Second Language Writing, Adolescent L2 Writing

\section{Introduction}

From a functional perspective, there are at least two major aspects in learning a language - learning how to mean, and learning how to mean in different registers. First, learning a language means learning how to mean in the language (Halliday \& Matthiessen 2013). Meaning-making is the heart of language learning, especially as it relates to how to make different texts function in different contexts. Mastering different types of texts operating in different contexts can help learners to make full use of the linguistic resources in meaning making. Second, learning a language also means accumulating different registers operating in different contexts, thus gradually expanding one's registerial repertoire (Matthiessen 1999). In order to expand their learners' registerial repertoires, language instructors must empower learners by facilitating their engagement with different types of texts in different contexts. Inspired by such a philosophy, this paper reports on how a class of students demonstrated their active linguistic repertoire of text types in the course of one year of writing. 


\section{Literature review}

Genre studies in primary and secondary education

Of the three schools of genre, the Sydney school is the only one that investigates primary and secondary school texts (Martin et al. 1987). Its philosophies and conceptions of genre originated from a project that explored students' written texts in various subjects in a disadvantaged school in Sydney, Australia. The purpose of the project was to help the underachievers to become competent in their learning through mastering different genres that primary and secondary education required. This school of genre has exerted tremendous influence on academics in Australia and is gradually receiving more attention from the rest of the world. Over the past decades, numerous studies have been conducted with the genre framework. The most influential study is probably the latest conducted by Christie and Derewianka (2008) and Christie (2012). This study sampled students' texts from primary to late secondary school across different subjects in Australia to investigate how their writing developed and what genres they needed to write across the school years before university. They identified typical genres in the students' writing in different subject areas and summarized the linguistic features. Similar studies, for example investigating the genres of history and English have also been conducted. Coffin (1996) identified the genres of history texts in secondary history textbooks to investigate how the discourse of history is construed, and summarized the challenges these genres posed for students. In English language course, Christie and Derewianka (2008) summarized all the genres that students were required to write in the Australian context. In addition, they mapped out the developmental changes of the linguistic resources required for learning these typical genres in English across the school years.

These recent studies in the Sydney school of genre have broadened and deepened our understanding of how to apply the model of genre to the investigation of texts that students are required to learn at school. In addition, they have also provided us with important insights into how students' writing develops ontogenetically throughout the school years, such as the developmental trajectory of students' genres and related lexicogrammatical resources in meaning making.

In the past decades, the Sydney school of genre has played an important role in identifying genres that students have to master in their schooling, which has helped educationalists and teachers to sequence the students' learning paths by arranging different genres at different stages. However, the Sydney school of genre hasn't yet provided us with a holistic view of what is the general distribution of text types or genres in students' learning. To do this, we need a more comprehensive model.

\section{Text typology studies}

As well as the genre studies, we also have other theoretical lenses for looking at texts, like text typology (Matthiessen et al. 2010; Matthiessen 2015). Earlier in 2006, Matthiessen (2006) attempted to conceptualize second language learning as the gradual expansion of a learner's registerial repertoire. Pun (2011) applied the context-based text typology to investigate texts from Hong Kong secondary chemistry textbooks and identified the major text types and their lexicogrammatical features. The text types and the lexicogrammatical features are of great importance to educationalists to summarize the linguistic challenges 
for ESL students in learning chemistry through English and how language functions in knowledge construal in chemistry learning. Teruya (2009) applied text typology to investigate how adult intermediate Japanese learners progressed from intermediate to advanced language learning by engaging with different text types. Guo (2015) investigated the registerial profiling of ESL textbooks from successive years of school in Hong Kong, which provided us with another perspective to see how input is arranged for ESL teaching and learning. However, as far as I can ascertain, no studies investigating learners' texts have adopted this model. This model is the one that has been adopted to conduct text type analysis with the data in the current study.

\section{Adolescent L2 Writing}

While interest in L2 writing research has increased exponentially in recent years, the body of research on adolescent L2 writing is relatively sparse (Matsuda and DePew 2002; Ortmeier-Hooper and Enright 2011). However, ever since Matsuda and DePew (2002) pointed out this paucity of literature on adolescent L2 writing in high school settings, we have seen a growing body of literature on this topic, consisting of various themes with different theoretical perspectives, including writing instruction (e.g., Kobayashi and Rinnert 2002), feedback (e.g., Lee 2008a 2008b), bilingualism and multilingualism (e.g., Enright 2011), government policy on writing practices (e.g., Enright 2011; McCarthey 2008), text analysis (e.g., Bunch \& Willett 2013; Lindgren and Stevenson 2013), genre and content writing (e.g., Harman 2013; Kibler 2010). Besides these major themes in adolescent L2 writing literature, we also see some emerging theoretical aspects used in the investigations of this group of writers. These include identity (e.g., Harklau 2000), L1 use (e.g., Kibler 2010), writing time allocation (e.g., Roca de Larios et al. 2008), students' reactions to process writing (e.g., Pennington et al. 1996), and Internet and adolescent L2 writing (e.g., Lam 2010). However, most of these studies have focused on writers in the North American context; few have investigated Chinese adolescent L2 writers.

\section{Theoretical Underpinnings}

\section{Defining register in systemic functional linguistics}

In systemic functional linguistics, register is regarded as the functional variety of language (Halliday and Matthiessen 2013). It consists of three variables, field, mode and tenor. These three variables define the context and the culture of communication socially and semiotically. In the present study, I will adopt the three variables of register to look at how the students configure their writing.

Field refers to what happen in the situation. There are two dimensions that we can focus on in field: social-semiotic activity and the experiential domain. Social semiotic activity is about the nature of the activity, while the experiential domain is about the experience of the activity.

Tenor refers to the totality of the relationships among people in the activity. There are several parameters that we can use to assess relationships in terms of tenor (Halliday and Matthiessen 2013), for instance, institutional roles, power relations, degree familiarity and affect. Institutional roles refer to the relationship between people in the activity. Power relations mean the power distribution among the people in the activity, such as high power vs. low power. Degree of familiarity refers to the extent of familiarity among people in the 
activity, such as strangers and friends. Affect refers to the attitude reflected from the activity, whether it is positive, neutral or negative.

Mode refers to the role of language or other semiotic resources played in the situation (Halliday and Matthiessen 2013), which consists of orientation, division of socio-semiotic labor, division of semiotic labor, medium and channel. Orientation means whether the nature of the activity is tenor-oriented (e.g. persuasive) or field-oriented (e.g. informative). Division of socio-semiotic labor means whether the activity is semiotic activity or the semiotic is just facilitating the activity, like writing an email and using GPS to find a place. Division of semiotic labor means the division of linguistic and the other semiotic activities, such as reading a novel vs. watching a movie. Medium means whether the activity is written or spoken. Channel means whether the activity is phonic or graphic.

\section{Defining Context-based text typology}

In this study I employed context-based text typology (Matthiessen 2006; Matthiessen 2015; Matthiessen \& Teruya 2014; Matthiessen et al. 2010; Teruya 2009) to analyse students' writing.

As Figs. 1 and 2 indicates, there are eight socio-semiotic processes based on different fields of activity in human life. The eight main types can be grouped into two superordinate categories, social process and semiotic process (Matthiessen 2015). Social process

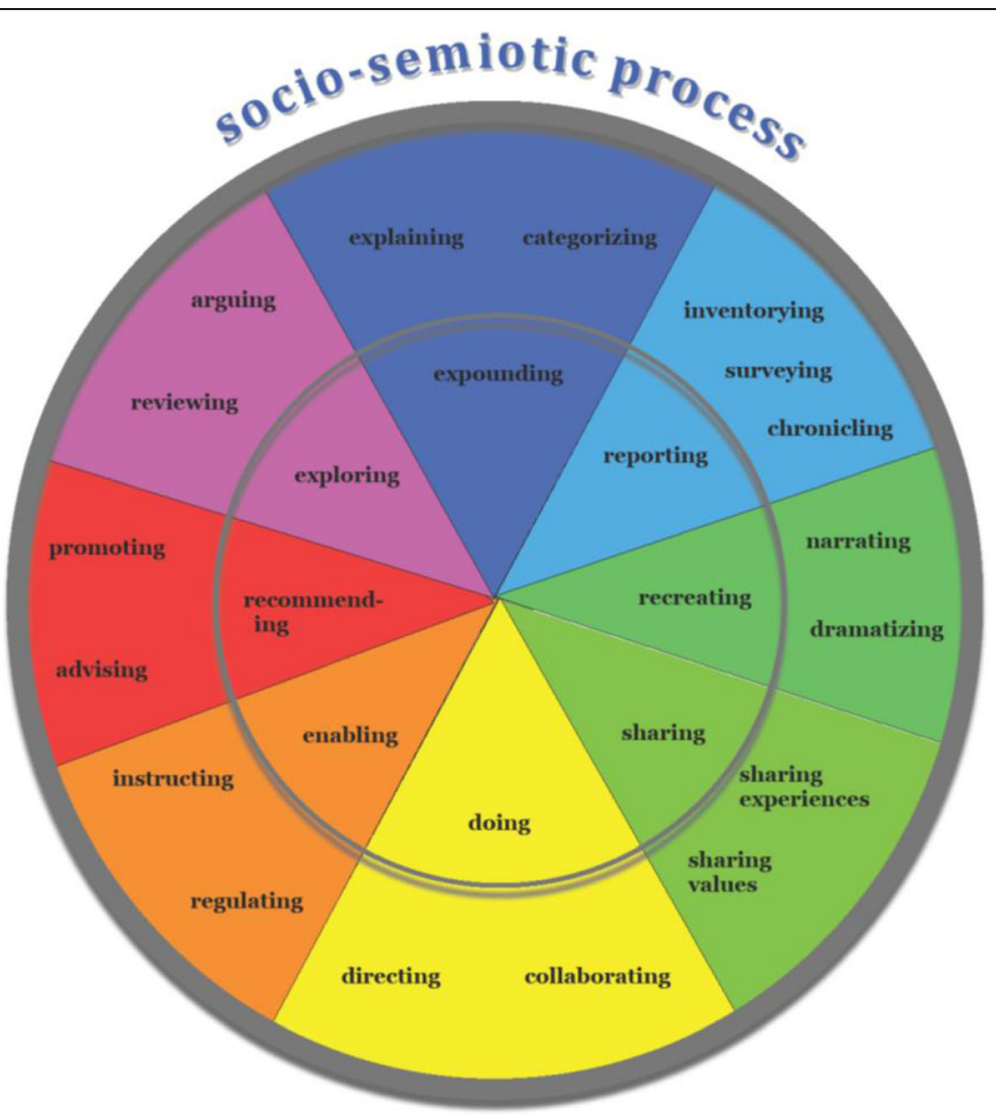

Fig. 1 Context-based text typology — field of activity 


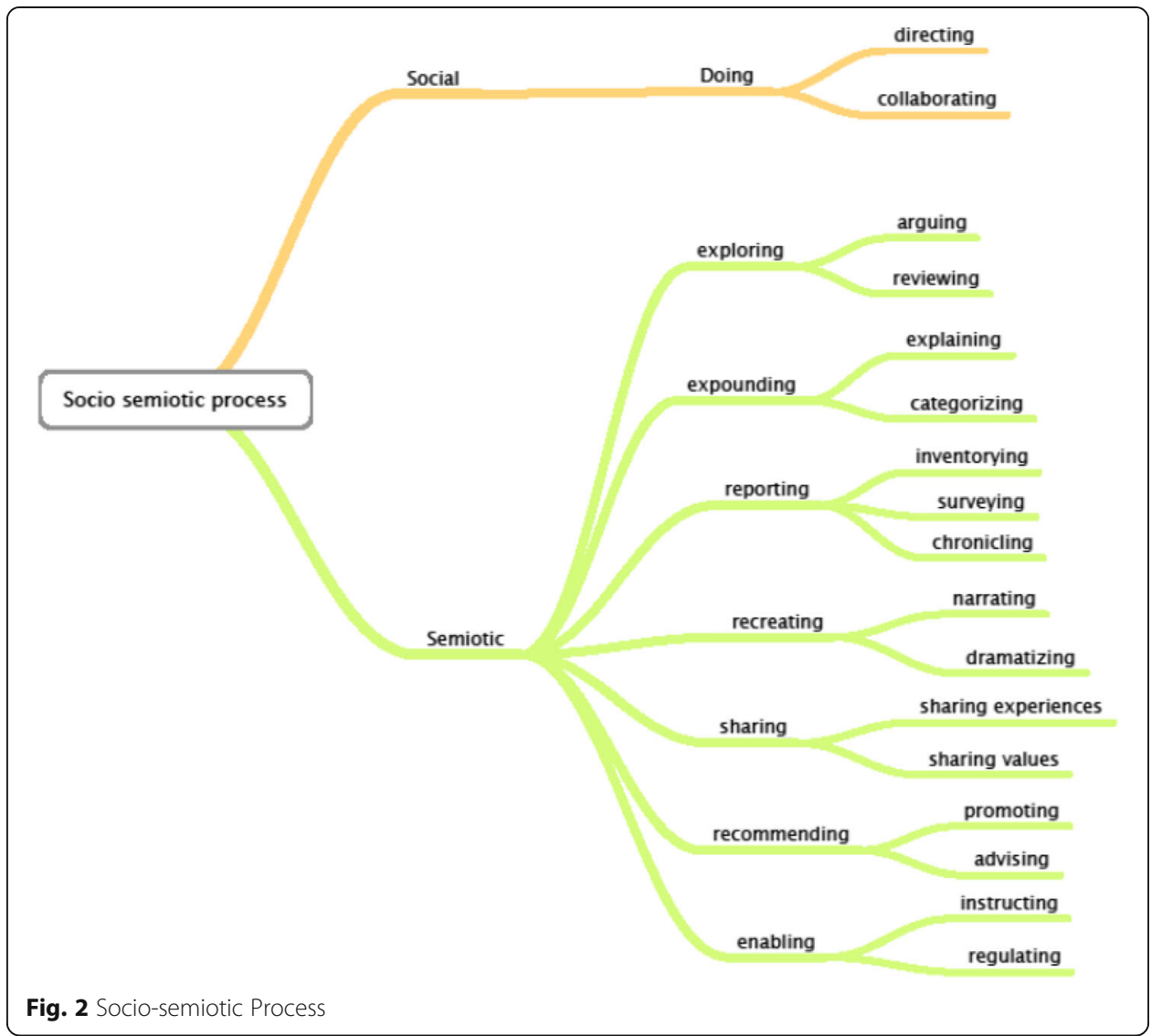

is realized by doing in this model, while semiotic process is realized by expounding, reporting, recreating, sharing, recommending, enabling and exploring.

(1) Expounding means the use of language or other semiotics to explain experiences or scientific knowledge. Expounding can be subdivided into categorizing and explaining, for example, in a chemistry text (Pun 2011).

(2)Reporting means the use of language or other semiotics to report experiences or other events in life. Reporting can be subdivided into chronicling a significant historical event (Coffin 1996), surveying a place or a person such as an interview, and inventorying particular entities such as a shopping list.

(3) Recreating means the use of language or other semiotics to reorganize experiences in life which are not real but imaginative for the purposes of entertainment. Recreating can be further divided into narrating such as in novels, and dramatizing such as in a drama.

(4) Sharing means the use of language or other semiotics to share personal lives for the purposes of maintaining interpersonal relations. There are two secondary types: sharing experiences and sharing values.

(5)Doing means the use of language or other semiotics to collaborate with others or direct others to finish a joint activity or task. There are two secondary types: collaborating and directing.

(6) Enabling means the use of language or other semiotics to carry out some activities such as instruction and regulation. 
(7)Recommending means the use of language or other semiotics to give advice or to promote something. The two secondary types are advising and promoting.

(8)Exploring means the use of language or other semiotics to explore human values and opinions on some topics. Exploring can be further divided into arguing and reviewing.

Such a paradigm, as proposed by Matthiessen (2015), for the study of text is relatively new in systemic functional text analysis. Its applications can be seen in different contexts, such as language education, healthcare communication, and translation studies. For example, Guo (2015) adopted such an approach, focusing on the texts from ESL textbooks used currently in the Hong Kong context and identified that such a text type approach could help ESL teachers to arrange texts for the instructed classroom learning.

\section{Methodology}

The study

The current study focused on texts written by junior secondary Chinese EFL learners at a school in Guangzhou. From the perspective of functional text analysis (Byrnes 2013), it aimed to explore what kinds of text types the junior secondary three students wrote and what textual features they deployed to construe meanings in the texts. The research questions were:

(1).Over a one-year longitudinal study, what kinds of text types/genres have students accomplished in their English writing?

(2).What kinds of textual features (for example, generic stages) are deployed in these ESL texts?

(3).For the identified text types, how do the students configure each text based on the three contextual variables of a register: field, tenor and mode?

\section{Research context and data collection Adolescent L2 English education in China}

Ever since the opening up reform, English has been taught widely in China (Liardét 2013). Studies by Wang and Gao (2008) found that China has the largest number of English learners in the world, amounting to approximately 400 million. English has become a compulsory subject from grade 3 for all primary and secondary school students (Liardét 2013). It is a major component of the National College Entrance Examination and has the same importance as Chinese and mathematics (Fang 2005), weighted as one-third of the final credits that students use when they apply for colleges. Since the examination plays an extremely important role in students' future development, the whole English curriculum serves it (Lee 2013; You 2004).

After conducting a thorough study of a mid-west Chinese university English program, You (2004) found that, in China, English teachers do not teach language per se but instead teach just language knowledge and test-taking skills. From my experience, this is even more the case for secondary school teachers in China. Among the test-taking skills that they teach, writing has become one of the testing items from secondary 3 onwards. From secondary 3 onwards, the teaching of writing tends to focus only on the 
skills needed in tests and examinations in English, which amount to approximately $30 \%$ of the students' final score for all subjects. Typically, teachers train students only in writing text types and in grammatical knowledge which are required for writing the examinations. This is high stakes for the students, as if they want to be successful in China, being able to write the English composition section of the examination is vital (Harklau 2011).

\section{Research site and participants}

The present study was conducted in a high school in Guangzhou, which is one of the top five high schools in this city. The school consists of junior secondary and senior secondary sections. A class of the 50 best students from secondary junior 3 was chosen as the participants for the study. The class consisted of 24 boys and 26 girls. They were in the final year of their junior high school, which is the end of the 9 years' compulsory education in China. The choice of such a school was inspired by what Christie and Derewianka (2008) did in Australia. They targeted the best students in each grade for study and delineated the possible linguistic repertoire that the students had mastered, aiming to give feedback to curriculum designers on what proficiency level the students could be expected to achieve.

The students receive 40 min of English instruction every day, from Monday to Friday. At junior secondary level, most of the instruction focuses on grammar and vocabulary learning, similar to what You (2004) found at the tertiary level. The students do endless multiple-choice questions to assess the accuracy of their grammar. Compared with grammar and vocabulary learning, actually practicing writing seems to take up less time in the current school system. The head of the English department told me during our discussion that the students would practice writing once in a month.

\section{Data collection and data analysis}

I collected the participants' English compositions for a whole academic year, yielding longitudinal data for more in-depth and elaborated understanding of the participants' L2 meaning repertoires (Ortega and Byrnes 2008). For this reason, I collected 10 English compositions from each participant during the data collection period.

Systemic functional text analysis (Byrnes 2009; Christie 2012; Christie and Derewianka 2008; Liardét 2013; Ryshina-Pankova and Byrnes 2013) was adopted for the present study. Following to Matthiessen (2015), I first went through the all the texts in the corpus I have built. I then identified the major purposes of each of the writing task. Finally, I identified the dominant linguistic/lexico-grammatical resources the students used in these writing.

\section{Results and findings}

\section{Background of the writing journey}

This section will deal with the ten writing tasks that the students addressed in their writing.

Table 1 shows the writing journey that the participants undertook during the two semesters at junior three. As indicated by the table, there were altogether ten writing tasks amounting to almost one per month. Most of the writing tasks were done under exam conditions, i.e. individually, at school and within a set of time limit. However, the first and sixth were take-home assignments.

In writing task one; the students were required to discuss the benefits of keeping smiling and how to keep up the habit of smiling at everyone and everything. The second task required the students to write a letter to provide some advice to a friend called Mike who 
Table 1 Writing tasks that students accomplished

\begin{tabular}{|c|c|c|}
\hline Time & Topic & Details \\
\hline 11th Sep 2011 & Learn to smile & Advise others to smile \\
\hline 11th Oct 2011 & A letter to Mike & Write a letter to a friend, who is sick recently. \\
\hline 11th Nov 2011 & Trip to Hangzhou & $\begin{array}{l}\text { Sharing your travelling experiences to Hangzhou } \\
\text { with your friends. }\end{array}$ \\
\hline 11th Dec 2011 & Steve Jobs & Describe Steve Jobs and his life. \\
\hline 12th Jan 2012 & Lifelong learning & Discuss lifelong learning and how to practice it. \\
\hline 12th Feb 2012 & An activity & Share an interesting activity. \\
\hline 12th Mar 2012 & A letter to Alice & $\begin{array}{l}\text { Write a letter to Alice and explain how to improve } \\
\text { her relationship with her Mum. }\end{array}$ \\
\hline 8th Apr 2012 & How to be a good learner? & State your views on how to be a good learner. \\
\hline 9th May 2012 & Micro blog & $\begin{array}{l}\text { Explore the advantages and disadvantages of micro } \\
\text { blog. State your views on it. }\end{array}$ \\
\hline 10th Jun 2012 & Charity sale & Share the charity sale took place in your school. \\
\hline
\end{tabular}

has often been sick recently, advising him how to lead a healthy lifestyle and maintain good health. The subsequent task was about sharing their experiences of a trip to Hangzhou. The students were required to retell the story of whole trip to Hangzhou to their friends. This provided opportunities for them to practice using past tense and different verbs and adjectives to describe their past experiences. The fourth task was on the topic of Steve Jobs, the deceased CEO of Apple. The students were required to recount Steve Jobs bio-information chronologically and comment on his life. The last writing task of the first semester was on the topic of lifelong learning. It required the students to interpret lifelong learning according to their own understanding and to give ideas about how to accomplish it. These were the first semester's writing tasks.

For the second semester, the first task was about retelling an activity that the students had experienced. The second writing task was a letter to a friend named Alice, who had communication problems with her mum. The students were required to write a letter and give some ideas on how to improve the relationship between Alice and her mum. The third writing task of the second semester was about learning. The topic focused on how to be a good learner. The students were required to provide different kinds of advice about this. The fourth writing task was about Micro Blog (a Chinese version of Twitter). The students were asked to discuss the advantages and disadvantages of Micro Blog and state their own opinions of it. The last writing prompt was about a charity sale. The students were asked to report a charity sale that they had experienced in their school.

These are the ten writing prompts that the students wrote in response to over a year of schooling, the period of my one-year longitudinal study. In the following sections, I am going to deconstruct the students' writing within the frameworks of the context-based text typology (Matthiessen et al. 2010; Matthiessen 2015), genre (Martin 2008) and the theory of register provided by Halliday (1978).

\section{Field of activity: socio-semiotic process}

Figure 3 maps out the writing journey that the students went through. Of the eight socio-semiotic processes classified by Matthiessen et al. (2010) and Matthiessen (2015), I have identified four text types that are deployed in the students' writing. They are recommending, sharing, reporting and exploring. Recommending is the most favored 


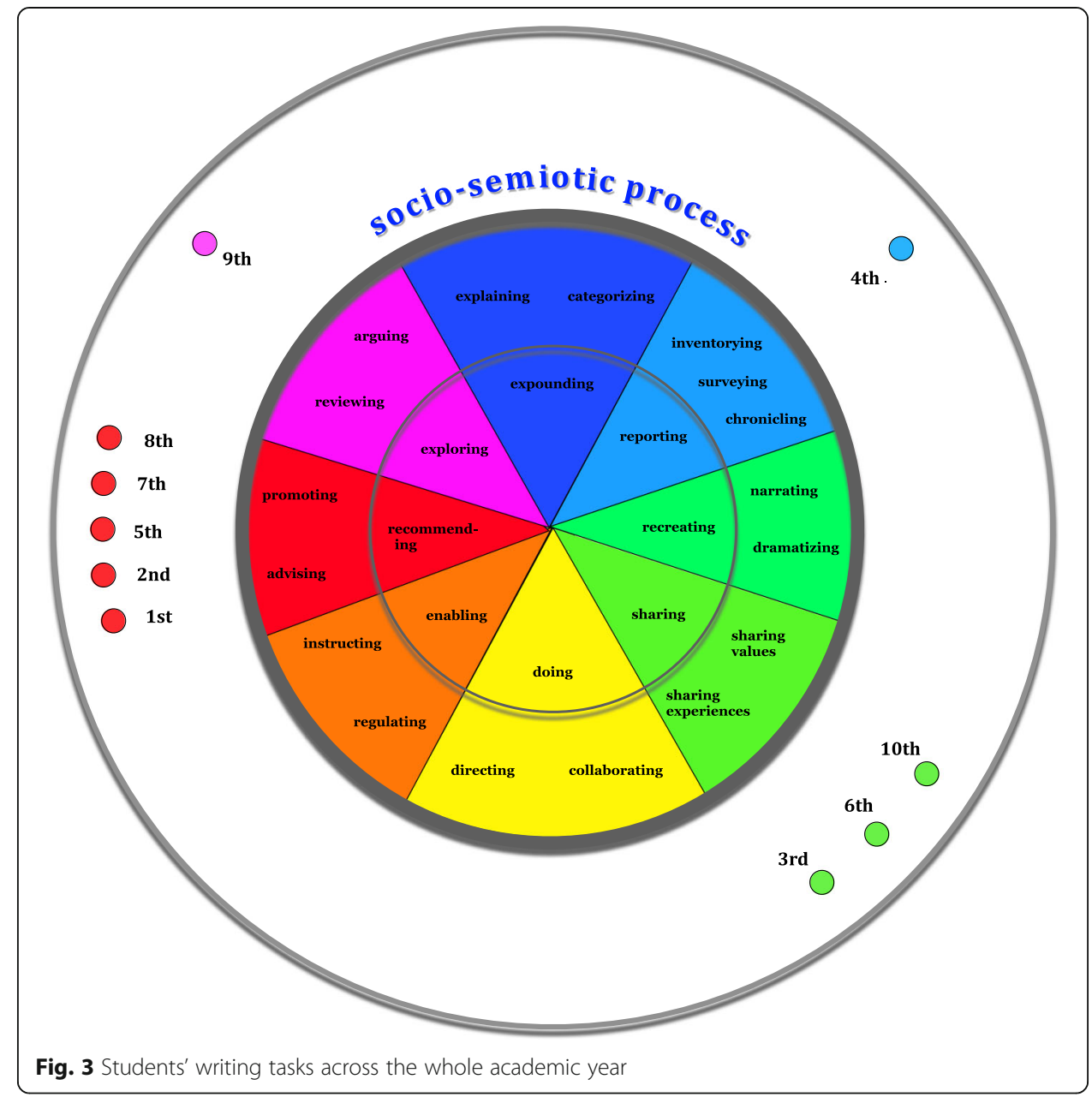

text type in the students' writing. It accounts for $50 \%$ of all the writing tasks. The second most favored type of text type is sharing, which accounts for $30 \%$ of all the students' writing. The fourth most favored types are exploring and reporting, which each accounts for $10 \%$ I found no instances of any other text types in the year of writing.

I then classified the text types to a further degree of delicacy of text typology, as shown in Fig. 4. In the context of recommending, most of the writing tasks are advising. The students were required to state their opinions on some issues that are related to their daily lives and provide their suggestions and ideas about how to solve the problems. All of the sharing texts belong to sharing experiences rather than sharing values, where students were required to retell or talk about their personal experiences. Under exploring, the students were required to argue rather than review. For example, under the topic the 'advantages and disadvantages of Micro Blog', the students were required to support their identification of advantages or disadvantages with argumentation. Under reporting, the writing task involved is chronicling. The students were asked to recount Steve Job's biographical information chronologically and to state their opinions of Steve in the end of the biographical recount.

I will use two cases from the students' writing to illustrate the two most favored text types: recommending and sharing. These two examples represent the two pieces of typical texts from the same student in my study: 


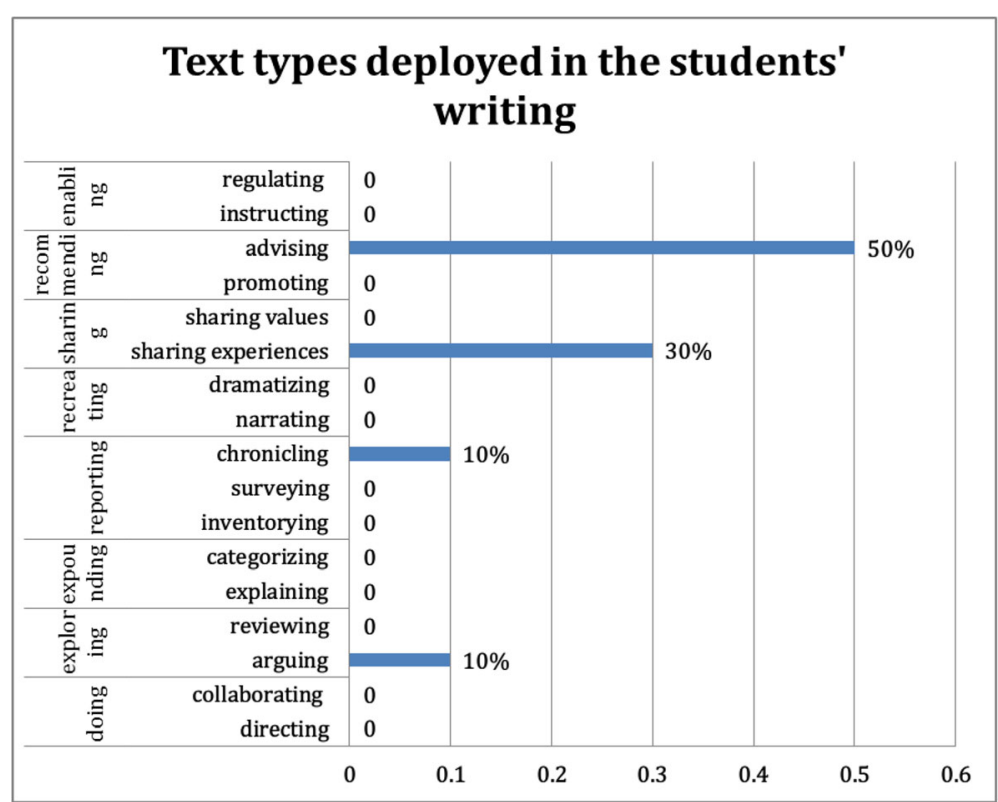

Fig. 4 Text types that deployed in the students' writing

Student Number: No.1, Title: A letter to Mike, Text type: recommending

Dear Mike,

[1] I am sorry to hear that you get sick easily these days. [2] Here are some advice about how to have a healthy lifestyle.

[3] First of all, pay attention to what you eat. [4] Having a balanced diet is quite important. [5] Drink at least eight glasses of water per day. [6] Avoid food which are high in salt or sugar. [7] They can make you get ill easily.

[8] Second, having a good rest do good to your health. [9] It's necessary for you to go to bed early. [10] Then you can get up early without feeling tired the next day. [11] Make sure you get plenty of rest-at least $8 \mathrm{~h}$ every day.

[12] Third, you should do some sports, for example, doing morning exercise carefully. [13] I've been having the habit of going jogging very morning for years. [14] It makes me stay healthy. [15.0] So I'll be very pleased [15.1] if you would like to join me.

[16.0] Though it might be take time to get used to the following advice, [16.1] if you insist, [16.2] I'm sure you'll be healthier soon.

Best wishes!

Yours,

Simon

Student Number: No.1, Title: Trip to Hangzhou, Text type: sharing

Dear Friend,

[1] Last summer holiday, I went to Hangzhou by air with my parents for a trip. [2] Let me introduce my adventure to you. [3] I'm sure you will fall in love with Hangzhou as I do!

[4] On the first day of the trip, I went to the famous West Lake to go boating. [5] It was relaxing to see all the beautiful scenery, including the bridges and houses built in traditional style. [6] I took lots of photos in order to memorize the amazing views.

[7] The next day, I visited a small village with houses which have a long history. [8.0] I met a foreign tourist excitedly [8.1] and even became friends! [9] It was such a valuable experience for me.

[10.0] Hangzhou is not only famous for its beautiful views, [10.1] but also its delicious food. [11] I got a chance to try the famous Dongpo Pork. [12] It was named by Su Dongpo, a great poet as well as a meat-lover in ancient China. [13] Dishes like the West lake fish and the Lion Head were worth trying too. [14] The food were so attractive that I put on much weight!

[15.0] Since Hangzhou was famous for its Dragon Well tea, [15.1] we went to shopping and bought some as gifts to friends. [16.0] Although the tea tasted good, [16.1] it was so expensive that I was shocked [16.2] when I saw the price!

[17] The trip to Hangzhou really made a deep impression on me. [18] It was one of the most fantastic cities I've Yours, ever been! [19] And I'm looking forward to visiting it again!

Simon 
These are two typical text types that I have identified in the students' writing. The first sample is recommending. The writer wrote a letter to his or her friend Mike, who was sick recently. The purpose of the letter is to greet Mike as well as to give him some advice on how to keep healthy. The writer started the letter with her greetings and continued to provide advice on how to keep healthy by listing the dos and don'ts. This is a typical recommending text from the students' writing.

The second text is about sharing the writer's experiences of traveling to Hangzhou. It is typical text of sharing: sharing experiences. The writer shared her experiences by writing a letter to her friend. She recounted her whole trip to her friend in a chronological way. She signalled the chronological organization of the text by deploying circumstances of time.

\section{Findings based on Halliday's theory of register and Martin's genre}

Drawing on Halliday \& Matthiessen (2013) framework of context, I have deconstructed the writing tasks to see how the students configured a piece of text according to the requirements of the settings of the contextual variables of field, tenor and mode. Tables 2 and 3 show the details of the outer, educational contexts of the writing tasks and the inner contexts of the texts produced in response to the different writing tasks.

As indicated in Table 2, the "outer" context of the students' writing is the same under the three variables: field, tenor and mode. The field is about practicing English composition. The tenor is concerned with teacher and students' relationships. The mode is spoken or written instruction. Therefore, there is no difference in the "outer" educational context among these writing tasks.

Based on the "outer" context to the "inner" context, Table 2 provides detailed information about each writing task. The following are the major findings of the inner context analyses.

\section{Field}

There are two sub-categories under field, socio-semiotic process and experiential domain. Socio-semiotic process is illustrated in the Section Field of activity: sociosemiotic process. The experiential domains are interpersonal behaviour (smiling), health, traveling, Jobs' life, lifelong learning, extracurricular activities, communication, good learner, micro blog and charity sale. All these experiential domains are relevant to the students' daily lives.

\section{Tenor}

As for institutional roles, $70 \%$ of them are not clear in the students' writing. Only the second, the third and the seventh writing tasks are clear. They are all letters by the students addressing their friends or family members. Power relations are also ambiguous. $70 \%$ of them are not clear while just 30\% are clear. The three letters are equal in terms of power, as they are all letters to friends. It is the same with 'familiarity'. $70 \%$ of all the writing tasks are not so clear on the degree of familiarity between readers and the writers. The three letters are clear in terms of 


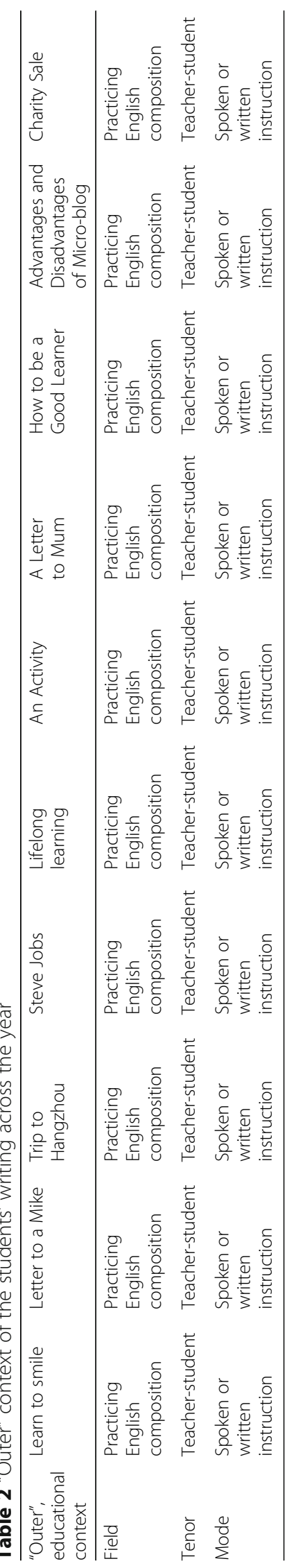




\begin{tabular}{|c|c|c|c|c|c|c|c|c|c|c|c|}
\hline 离 & 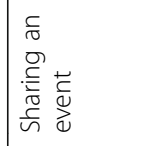 & 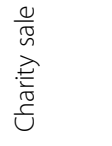 & 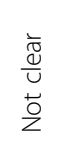 & 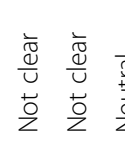 & $\frac{\bar{d}}{\stackrel{\overrightarrow{0}}{\vec{v}}}$ & 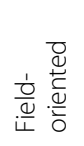 & 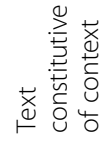 & 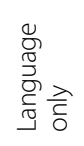 & 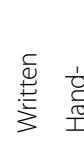 & & 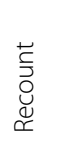 \\
\hline 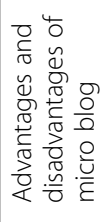 & 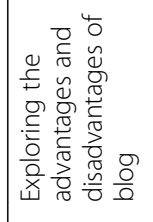 & 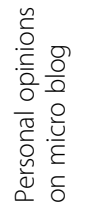 & 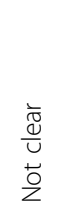 & 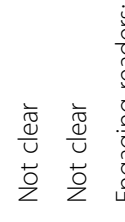 & 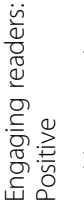 & 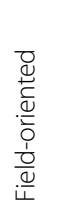 & 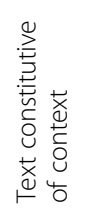 & 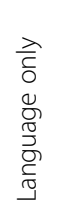 & $\begin{array}{ll} \\
\end{array}$ & & 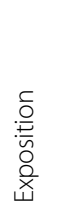 \\
\hline 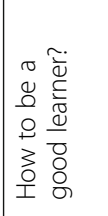 & 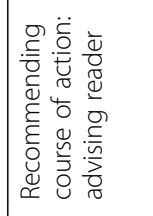 & 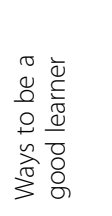 & $\begin{array}{l}\frac{\bar{d}}{\tilde{U}} \\
\frac{0}{0} \\
z\end{array}$ & 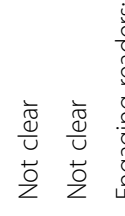 & 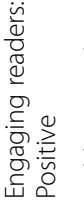 & 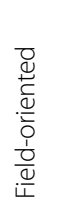 & 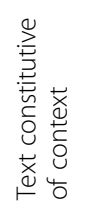 & 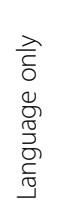 & 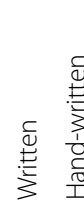 & & 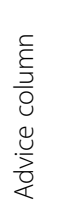 \\
\hline 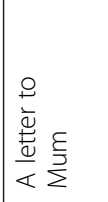 & 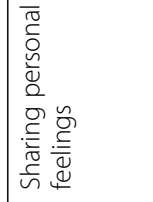 & 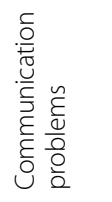 & $\begin{array}{l}\frac{E}{5} \\
\sum_{0} \\
0 \\
\frac{t}{0} \\
\frac{0}{\bar{U}}\end{array}$ & 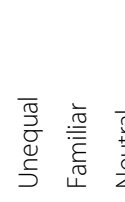 & 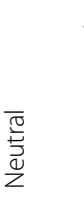 & 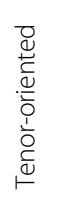 & 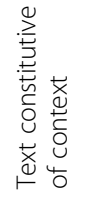 & 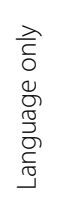 & & & $\begin{array}{l}\frac{\tilde{\xi}}{\bar{z}} \\
\frac{0}{0} \\
\frac{\tilde{y}}{z} \\
\frac{0}{\alpha}\end{array}$ \\
\hline 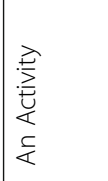 & 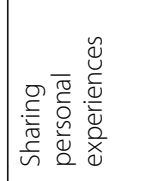 & 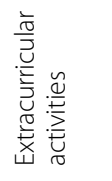 & 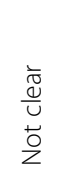 & 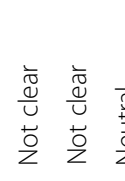 & 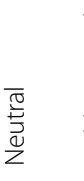 & 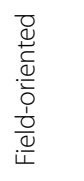 & 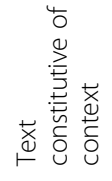 & 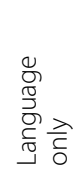 & 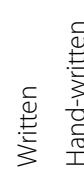 & & 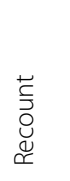 \\
\hline 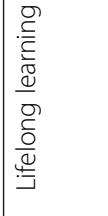 & 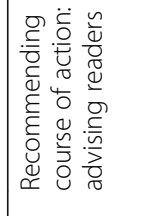 & 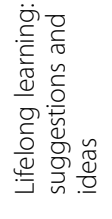 & 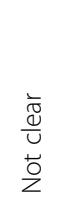 & 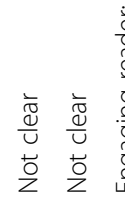 & 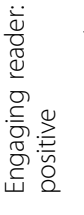 & 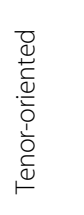 & 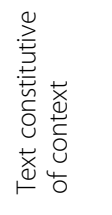 & 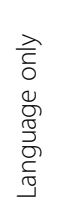 & & & 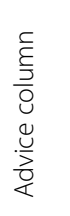 \\
\hline 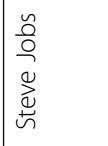 & 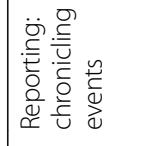 & 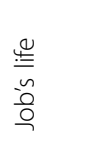 & 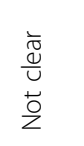 & 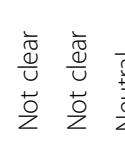 & 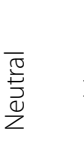 & 竞 & 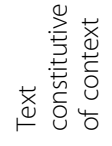 & 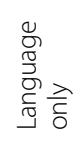 & 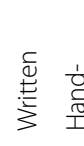 & $\frac{c}{\stackrel{巳}{*}}$ & 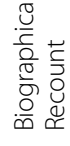 \\
\hline 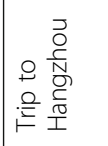 & 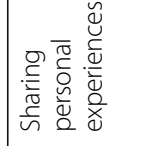 & 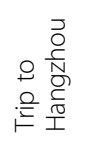 & 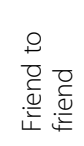 & $\bar{z}$ & $\begin{array}{l}\overline{\frac{\pi}{0}} \\
\frac{\vec{v}}{2} \\
\frac{0}{2}\end{array}$ & 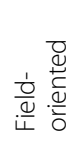 & 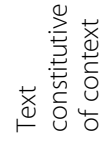 & 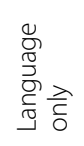 & 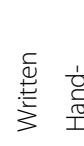 & 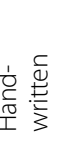 & 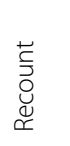 \\
\hline 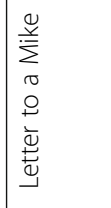 & 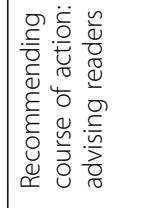 & 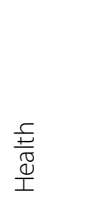 & 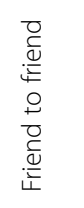 & 可高 & 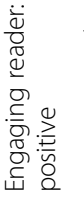 & 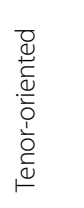 & 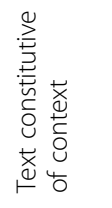 & 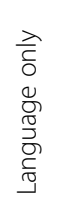 & 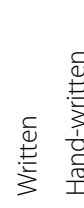 & & 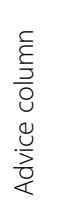 \\
\hline 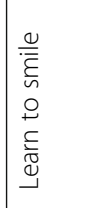 & 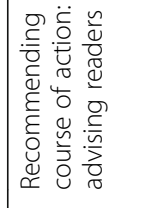 & 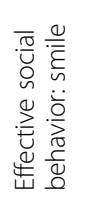 & $\begin{array}{l}\frac{\bar{d}}{\tilde{d}} \\
\stackrel{0}{z}\end{array}$ & 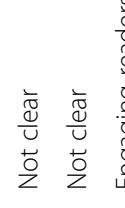 & 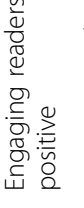 & 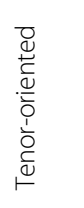 & 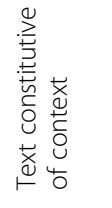 & 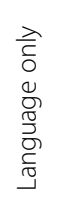 & 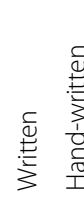 & & 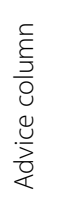 \\
\hline & 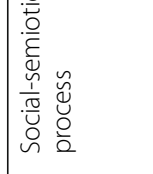 & 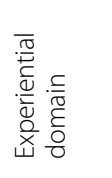 & 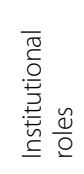 & 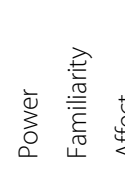 & 芯 & 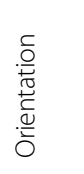 & 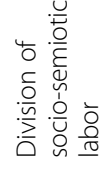 & 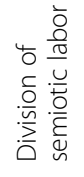 & 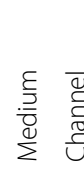 & & \\
\hline$\subseteq \bigcup^{4}$ & & & 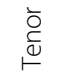 & & & $\begin{array}{l}\frac{0}{0} \\
\frac{0}{2}\end{array}$ & & & & & \\
\hline
\end{tabular}


the degree of familiarity, which accounts for $30 \%$ of all the writing tasks. For affect, half of the writing tasks involve engaging the readers positively, while the rest of the writing tasks are neutral. The 1st, 3rd, 5th, 8th and 9th writing tasks engage the reader positively by writing about smiling, lifelong learning, health, be a good learner and opinions on Micro Blog. The rest of the writing tasks are neutral in affect.

\section{Mode}

As indicated in Table 2, most of the writing tasks are the same with these five variables, except orientation. In orientation, half of the writing tasks are tenororiented, such as the letters that the students were asked to write. The other half of the writing tasks are field oriented, such as the trip to Hangzhou, Steve Jobs. The students were required to construe their experiences to realize the meaning potentials in these writing tasks. The division of socio-semiotic labour is text constitutive of context. The division of semiotic labour is language only. The medium is written. The channel of the communication is hand-written. These are all the same in these writing tasks.

\section{Genre}

Based on the field of activities these students have gone through, I shall now draw on Martin's description of genres (e.g. Martin and Rose 2008) to identify genres in the students' writing and to map their generic stages. Three such genres can be identified in the students' writing. They are advice, recount and exposition. The 1st, 2nd, 5th, 7th and 8th writing tasks are advice genre. The 3rd, 4th, 6th and 10th are recount genre. The 9th is exposition genre. I will now illustrate the schematic structure of a typical text of each genre that I have identified in these texts (Table 4).

\section{Sample one: Genre of Advice}

Title: A letter to Mike, Student: No.1 Time of writing: 2nd.

\begin{tabular}{|c|c|}
\hline Generic stages & Sample text \\
\hline $\begin{array}{l}\text { Statement of the } \\
\text { purpose }\end{array}$ & $\begin{array}{l}\text { Dear Mike, } \\
\text { [1] I am sorry to hear that you get sick easily these days. [2] Here are some advice about } \\
\text { how to have a healthy lifestyle. }\end{array}$ \\
\hline Suggestion one & $\begin{array}{l}\text { [3] First of all, pay attention to what you eat. [4] Having a balanced diet is quite } \\
\text { important. [5] Drink at least eight glasses of water per day. [6] Avoid food which are high } \\
\text { in salt or sugar. [7] They can make you get ill easily. }\end{array}$ \\
\hline Suggestions two & $\begin{array}{l}\text { [8] Second, having a good rest do good to your health. [9] It's necessary for you to go to } \\
\text { bed early. [10] Then you can get up early without feeling tired the next day. [11] Make } \\
\text { sure you get plenty of rest-at least } 8 \text { h every day. }\end{array}$ \\
\hline Suggestion three & $\begin{array}{l}\text { [12] Third, you should do some sports, for example, doing morning exercise carefully. } \\
\text { [13] I've been having the habit of going jogging very morning for years. [14] It makes } \\
\text { me stay healthy. [15.0] So I'll be very pleased [15.1] if you would like to join me. }\end{array}$ \\
\hline End of the letter & $\begin{array}{l}\text { [16.0] Though it might be take time to get used to the following advice, [16.1] if you } \\
\text { insist, [16.2] I'm sure you'll be healthier soon. } \\
\text { Best wishes! } \\
\text { Yours, } \\
\text { Simon }\end{array}$ \\
\hline
\end{tabular}


Table 4 Comparison between the two models: socio-semiotic process and genre

\begin{tabular}{|c|c|c|c|c|}
\hline \multicolumn{2}{|c|}{ Field: Socio-semiotic process } & \multirow{2}{*}{$\begin{array}{l}\text { Genre } \\
\text { Biographical recount }\end{array}$} & \multirow{2}{*}{$\begin{array}{l}\text { Generic stages } \\
\text { Orientation } \\
\text { Recount of the events } \\
\text { Moral lesson }\end{array}$} & \multirow{2}{*}{$\begin{array}{l}\text { Writing tasks } \\
\text { th }\end{array}$} \\
\hline Reporting & 'Chronicling & & & \\
\hline Sharing & Experiences & Personal recount & $\begin{array}{l}\text { Orientation } \\
\text { Recount of the events }\end{array}$ & 3rd, 6th and 10th \\
\hline Recommending & Advising & Advice & $\begin{array}{l}\text { Statement of the purpose } \\
\text { Suggestions }(1.2 .3 \ldots) \\
\text { Ending }\end{array}$ & 1st, 2nd, 5th, 7th and 8th \\
\hline Exploring & Arguing & Exposition & $\begin{array}{l}\text { Specification of the issue } \\
\text { Pro and cons } \\
\text { Statement of opinion }\end{array}$ & 9th \\
\hline
\end{tabular}

\section{Sample two: Genre of recount}

Title: Steve Jobs, Student: No.1 Time of writing: 4th.

\begin{tabular}{ll}
\hline $\begin{array}{l}\text { Generic stages } \\
\text { Orientation }\end{array}$ & $\begin{array}{l}\text { Sample text } \\
\text { [1] Steve Jobs was famous as the former CEO of Apple Inc. [2] He was a man full of } \\
\text { wisdom. [3] During his life, he never gave up. }\end{array}$ \\
$\begin{array}{l}\text { Recount of the } \\
\text { events }\end{array}$ & $\begin{array}{r}\text { [4] In his 20s, he set up Apple Inc. in his parents' garage. [5] Nine years later, he was fired } \\
\text { unfortunately. [6] However, failure didn't knock him down. [7] He found his aim again } \\
\text { several months later. [8.0] He tried his best to work hard [8.1] and set up two more } \\
\text { companies within five years. [9] The companies achieved great success. [10] Jobs soon } \\
\text { became popular all around the world. } \\
\text { [11] 'Nothing is impossible to a willing heart.' [12] According to Jobs's story, we can learn that } \\
\text { nothing is really over until the moment we stop trying. [13] So don't be afraid of fighting } \\
\text { against difficulties. [14.0] Our dream will surely come true [14.1] as long as we insist. }\end{array}$ \\
\hline
\end{tabular}

These are the two typical instances of genres that I have identified in the students' writing.

\section{Discussion}

\section{Recommending as the dominant text type}

Among the four text types that I have identified, recommending is the most favored text type in the students' writing. Interestingly, there is no text that could fit into Matthiessen's criteria of recommending from what Christie and Derewianka (2008) found in the Australian context. In the Australian context, secondary school students wrote more recreating texts. According to Christie and Derewianka (2008), there is no instance of a recommending text found in the whole writing journey at secondary level. However, half of the writing prompts in the present study are recommending texts. Teachers favor assigning tasks in which the students should provide suggestions or advice, such as how to keep smiling, how to be a good learner. The reason why teachers favor this type of writing tasks is because of the exam driven culture. In China, the exam still plays an essential role in assessing students' academic performance (Lee 2013). Most of these writing tasks follow the style writing exam requirement. That is why the students in my study have written so many texts that are similar in terms of field of activity in their writing practice. 


\section{Tenor awareness}

Through the analysis of the "inner" context, I have found some very important details about tenor building in the students' writing. Based on what I have found, most of the writing tasks are not clear about tenor relationship building. From the perspectives of outside observer, they didn't provide enough tenor information with the writing prompts that they assigned to the students. No tenor awareness is demonstrated in these writing prompts. From the perspectives of the students, due to the lack of explicit information from the writing prompts provided, it appears that the students were never taught about the importance of developing the ability to write texts in contexts characterized by an increasing range of tenor values over time as they continue to learn to write texts belonging to different registers. Because of this, the texts written by them were ambiguous about who is the addressee of the writing task. That is why we don't know whom are they addressing when we read their writing. So, if the teachers are aware of this and provide more detailed information on tenor, the students definitely will be more informed on how to build up the field and the interpersonal relationships between themselves and their imagined readers.

\section{Culturally marked text}

From the contextual analysis of these texts, we can learn that all these compositions are culturally marked. The students tend to end their texts with a part that focuses on moral or educational lesson. They attempt to educate their cohorts by concluding their writing on the topic or issues arising in their writing tasks. I will illustrate this with some sample extracts from their writing.

In the reporting texts, after recounting Jobs' life, the writers like to end their writing by exhorting their cohorts to learn from Jobs:

[12] According to Jobs's story, we can learn that nothing is really over until the moment we stop trying.

[13] So don't be afraid of fighting against difficulties.

[14.0] Our dream will surely come true [14.1] as long as we insist.

(Extract from student No.1, 4th writing)

In recommending, after discussing the advantages of lifelong learning, the writers end their texts by advising their fellow students to practice the principle of lifelong learning. Here is an example from a student's extract:

[12] In the way remembering that " the secret of success is the constancy of hard work,"

[13] we may have a more positive attitude towards lifelong learning.

[14] I think the idea of lifelong learning should be widespread in order to live a more well-being life.

(Extract from student No. 6, 5th writing)

As we can see from the samples above, no matter in which context, the students tend to address similar moral lessons at the end of their texts. 


\section{Variations of genres}

The genres that I have identified in the present study have their own characteristics. Motivated by the methodology deployed by Martin and Rose (2008) in describing genres, I have summarized the students' texts. Genres of advice, recount and exposition have been identified. However, when I attempted to map out their generic stages, I found that genres from the present study have differences and similarities to the genres described by Martin and Rose (2008), or Christie and Derewianka (2008). As we can see from the generic stages set out in Section Genre, some of the differences are as follows: in addition to the typical stages in a specific genre, in every genre the writers tend to end their writing with some suggestions or ideas to seek to educate their cohorts. Furthermore, most of the advice appears in the form of a letter. Some of the advice is configured by different pieces of suggestions throughout the letter, while others are constituted of explanation of phenomenon and then suggestions. These are the variations that I have found in the ESL context.

\section{Conclusion}

This paper has summarized the text types and genres that the students have written in this longitudinal study. The findings from text type analysis indicate that there is an uneven distribution of text types in the students' learning. Of all the ten writing tasks I have investigated, recommending is the most favoured text type. Moreover, only four text types have been identified in the students' writing. They are recommending, sharing, exploring and reporting. The contextual analysis shows that the teachers and the students lack tenor awareness in the L2 writing instruction and writing. At the end of the paper, I have proposed the adoption the framework of register theory to empower the teachers to improve their instruction. Furthermore, teachers or educationalists could arrange the writing tasks in a more scientific way that they could track how well the students' progress, which is aligned with what Matthiessen (2006) pointed that learners expand their personal meaning potentials by adding registers to their registerial repertories. The findings from this paper have shed some light on the teaching of ESL writing and the design of the writing curriculum.

Though the present study has yielded many findings concerning adolescent L2 writing from systemic functional text analysis, as it is still an exploratory study in nature, its limitations should be spelled out when we want to implement and interpret these findings. In discussing the limitations of this study, I will focus mainly on representativeness and generalizability of the findings, exhaustiveness of the analytical coverage and nature of the data. For representativeness and generalizability of the findings, the number of participants for the present study is also very small. I have just included a class of the 50 best students in one of the top five high schools in Guangzhou. With this participant limitation, we need to be cautious in generalizing the findings. If we can include more schools with different cultures into the present study, the results might be more generalizable. For nature of the data, the findings of the present study only were generated from text analysis. I haven't included any information about the teachers and the students on how do they perceive L2 writing instruction and their texts. Lack of this ethnographic information also may weaken the reliability of the findings to some extent. All these limitations remind us the applicability of the findings from the present study should be cautious and careful. 
For better generation of the findings for similar studies, we should attempt to include more participants from different institutions, which can add more different elements into the data in order to generate more reliable findings with certain representativeness. Furthermore, we can include voices of writing teachers and students into our analysis, which could add more interesting insights from the perspective of human agency. Once we obtain all of this information, we can learn more about the ecological system of adolescent L2 writing from different channels in a more comprehensive way.

\section{Competing interests}

The author declares that he has no competing interests.

Received: 20 August 2016 Accepted: 28 December 2016

Published online: 28 January 2017

\section{References}

Bunch, G.C., and K. Willett. 2013. Writing to mean in middle school: Understanding how second language writers negotiate textually-rich content-area instruction. Journal of Second Language Writing 22(2): 141-160.

Byrnes, H. 2009. Emergent L2 German writing ability in a curricular context: a longitudinal study of grammatical metaphor. Linguistics and Education 20(1): 50-66.

Byrnes, H. 2013. Curricular thinking in language education: Why does it matter? The 4th PolySystemic: Language \& Education Symposium, The Hong Kong Polytechnic University.

Christie, F. 2012. Language education throughout the school years: a functional perspective. Language learning monograph series. USA: Wiley-Blackwell.

Christie, F., and B. Derewianka. 2008. School discourse: learning to write across the years of schooling. London: Continuum.

Coffin, C. 1996. Exploring Literacy in School History. Erskineville: Metropolitan East Disadvantaged Schools Program, NSW Dept. of School Education.

Enright, K.A. 2011. Language and literacy for a New Mainstream. American Educational Research Journal 48: 80-118.

Fang, Z. 2005. Scientific literacy: A systemic functional linguistics perspective. Science education 89(2): 335-347.

Guo, S. 2015. The ontogenesis of multiliteracies in textbooks: multimodal analysis of english language teaching textbooks of different grades (Doctoral dissertation, The Hong Kong Polytechnic University).

Halliday, M.A.K. 1978. Language as social semiotic: the social interpretation of language and meaning. London: Edward Arnold. Halliday, M.A.K., and C.M.I.M. Matthiessen. 2013. Halliday's introduction to functional grammar. Ney York: Routledge.

Harklau, L. 2000. From the "Good Kids" to the "Worst": Representations of English language learners across educational settings. TESOL Quarterly 34: 35-67.

Harklau, L. 2011. Commentary: adolescent L2 writing research as an emerging field. Journal of Second Language Writing 20(3): 227-230.

Harman, R. 2013. Literary intertextuality in genre-based pedagogies: building lexical cohesion in fifth-grade L2 writing Journal of Second Language Writing 22(2): 125-140.

Kibler, A. 2010. Writing through two languages: first language expertise in a language minority classroom. Journal of Second Language Writing 19(3): 121-142.

Kobayashi, H., and C. Rinnert. 2002. High school student perceptions of first language literacy instruction: implications for second language writing. Journal of Second Language Writing 11: 91-116.

Lee, I. 2008a. Student reactions to teacher feedback in two Hong Kong secondary classrooms. Journal of Second Language Writing 17: 144-164.

Lee, I. 2008b. Understanding teachers' written feedback practices in Hong Kong secondary classrooms. Journal of Second Language Writing 17: 69-85.

Lee, I. 2013. Becoming a writing teacher: using "identity" as an analytic lens to understand EFL writing teachers' development. Journal of Second Language Writing 22(3): 330-345.

Liardét, C.L. 2013. An exploration of Chinese EFL learner's deployment of grammatical metaphor: learning to make academically valued meanings. Journal of Second Language Writing 22(2): 161-178.

Lindgren, E., and M. Stevenson. 2013. Interactional resources in the letters of young writers in Swedish and English. Journal of Second Language Writing 22(4): 390-405.

Martin, J., \& Rose, D. 2008. Genre relations: Mapping culture. Equinox.

Martin, J. R., Christie, F., \& Rothery, J. 1987. Social processes in education: A reply to Sawyer and Watson (and others). The place of genre in learning: Current debates, 35-45.

Matsuda, P.K., and K.E. DePew. 2002. Early second language writing: an introduction. Journal of Second Language Writing 11: 261-268.

Matthiessen, C.M.I.M. 1999. The system of TRANSITIVITY: an exploratory study of text-based profiles. Functions of Language 6(1): 1-51.

Matthiessen, C.M.I.M. 2006. Educating for advanced foreign language capacities: Exploring the meaning-making resources of languages systemic-functionally. Advanced language learning: The contribution of Halliday and Vygotsky, 31-57.

Matthiessen, C.M.I.M. 2015. Register in the round: registerial cartography. Functional Linguistics 2(1): 1.

Matthiessen, C.M.I.M., K. Teruya, and M. Lam. 2010. Key terms in systemic functional linguistics. London \& NewYork: Continuum. McCarthey, SJ. 2008. The impact of No Child Left Behind on teachers' writing instruction. Written Communication 25: $462-505$.

Ortega, L., and H. Byrnes. 2008. The longitudinal study of advanced L2 capacities. Ney York: Routledge. 
Ortmeier-Hooper, C., and K.A. Enright. 2011. Mapping new territory: toward an understanding of adolescent L2 writers and writing in US contexts. Journal of Second Language Writing 20(3): 167-181.

Pennington, M.C., M.N. Brock, and F. Yue. 1996. Explaining Hong Kong students' response to process writing: an exploration of causes and outcomes. Journal of Second Language Writing 5: 227-252.

Pun, K.H. 2011. Analysis of Hong Kong science textbooks using systemic functional approach (Unpublished MA). Hong Kong: The Hong Kong Polytechnic University.

Roca de Larios, J., R. Mancho'n, L. Murphy, and J. Marı'n. 2008. The foreign language writer's strategic behaviour in the allocation of time to writing processes. Journal of Second Language Writing 17: 30-47.

Ryshina-Pankova, M., and H. Byrnes. 2013. Writing as learning to know: tracing knowledge construction in L2 German compositions. Journal of Second Language Writing 22(2): 179-197.

Teruya, K. 2009. Grammar as a gateway into discourse: a systemic functional approach to SUBJECT, THEME, and logic. Linguistics and Education 20(1): 67-79.

Wang, W., and X. Gao. 2008. English language education in china: a review of selected research. Journal of Multilingual and Multicultural Development 29(5): 380-399.

You, X. 2004. "The choice made from no choice": English writing instruction in a Chinese University. Journal of Second Language Writing 13(2): 97-110.

\section{Submit your manuscript to a SpringerOpen ${ }^{\circ}$ journal and benefit from:}

- Convenient online submission

$\checkmark$ Rigorous peer review

- Immediate publication on acceptance

Open access: articles freely available online

- High visibility within the field

Retaining the copyright to your article

Submit your next manuscript at $\boldsymbol{\nabla}$ springeropen.com 